\title{
Integrated Model To Analyze FDI Role In Success of Commercialization of High-Tech Innovations in Asia
}

\author{
Sarli Rahman ${ }^{1}$, Andi $\mathrm{Oh}^{2}$, Yusrizal ${ }^{3}$
}

\begin{abstract}
:
This study aims to analyze the role of FDI in the success of commercialization high tech innovation in Asia countries. The success was marked by the increasing contribution from Asia countries to the export value of high tech products in the world.

From 49 sovereign countries in Asia, 21 countries have been selected as research samples. The result SEM analysis shows that FDI inflows to Asia countries generally pure investment from multinational companies to gain profits from the low cost of production factor in Asia, therefore increase their profit margin.

In other words, FDI in Asia countries only increase production quantity of high tech products without increasing innovation activity in the countries, which innovation activity can be measured by $R \& D$ expenditure, number of resident patent application and number of scientific journals international publication.
\end{abstract}

Keywords: FDI, commercialization of innovation, high tech export, Asia countries

\footnotetext{
${ }^{1}$ School of Business Pelita Indonesia, Dept of Management, sarli.rahman@lecturer.pelitaindonesia.ac.id

${ }^{2}$ School of Business Pelita Indonesia, Dept of Management, andi.oh@bgp-import.co.id

${ }^{3}$ School of Business Pelita Indonesia, Dept of Management, yusrizal@lecturer.pelitaindonesia.ac.id
} 


\section{Introduction}

Today, many Asia country no longer dependent on natural resources, but have switched to innovative products and services include high tech product trading. This is showed from the increasing trend total export value of high tech products in Asia countries from years 2000 to 2016. World Bank shows that a contribution of Asia countries to the value of high tech products export in the world increased. In 2000, Asia countries only contributed $34,84 \%$, then in 2016 they already contributed $51,70 \%$ from the total export of high tech products in the world. This means more half than world high tech export comes from Asia countries.

Acceleration of high tech export in Asia countries caused by their success in accomplish much innovation in technology and commercialize it. Pioneered by China, Japan, Korea, and Singapore, Asia countries make big investments in Research \& Development activity. R\&D expenditures in countries such as Korea, China and Malaysia increased two times in 2016 compared to their expenditure in 2000. While Japan, always maintain their R\&D expenditures above $2,5 \%$ from their national Gross Domestic Product (GDP).

Innovation is a locomotive of economic growth amid uncertainty caused due to rapid changes in the economic environment. Doing innovation continuously and sustainable is the main key to increasing competitiveness. Economic entity with high levels of innovation will be more independent in the market and more aggressive towards competition (Igor, 2005), this is because they are more productive in developing new products or making significant improvements to existing products by conducting R\&D activities. Look at how Malaysia is no longer dependent on exports of its natural resources but has switched to the exports of high tech by conducting R\&D activities (Akoum, 2016).

It is undeniable that $R \& D$ activities are the backbone of innovation, but the problem is not easy in measuring the performance of $R \& D$, because of the high uncertainty. So that in measuring the performance of $\mathrm{R} \& \mathrm{D}$, in addition to using its expenditure as input of innovation, can also use a proxy in the form of publication data that is used to estimate the results of basic research and data on the number of patent applications as the output of innovation (Melkers et al, 1993). Also, patent data can also be used to measure the invention, innovation, or technology changes (Prasanna, 2010).

Besides being able to increase productivity and competitiveness, innovation can also attract investment from overseas. The Economy with high innovation can attract more foreign investment, because of the chances to get the first advantage from new product launching in the market. In economics term this foreign investment known as Foreign Direct Investment (FDI). The relationship between FDI and innovation already got attention from many researchers. One of the important factors that are 
believed influences R\&D activities is the FDI level (Qayoom \& Ruchi, 2017), in which FDI contributes to innovation activity development (Gervais, 2009).

However, there is still theoretical ambiguous related the relationship between innovation with FDI, one of them is related to the protection of Intellectual Property Rights (IPR) in this case including patents, copyright, trademark, and trade secret to FDI, which some of the studies showed inconsistent results (Adams, 2010). Some of the studies found that IPR gives a positive effect on FDI (Lesser, 2002; Javorcik, 2004; Khan \& Samad, 2010; Adams, 2010). Meanwhile, other studies found that every increase of one unit's FDI value will increase the number of patents (Ghazal \& Zulkhibri, 2015). On the other side, some results found that FDI gave a negative effect on R\&D activities (Anwar \& Sun, 2014). Also besides there is inconsistent studies' result relate to the relationship between FDI and export performance in a country. A study concluded that FDI has significantly contributed to improving export performance in India between the years 1991-1992 and 2006-2007 (Prasanna, 2010). FDI also can enhance the success chances of innovation in Malaysia (Ismail, 2013). Furthermore, he stated that in the high tech sector, FDI and export complete each other. However other studies concluded that FDI gave a negative effect on high tech product export (Ilmi, 2017).

Differences result in previous studies one of them caused by differences in identified the roles of FDI on innovation activities in a country. In this research at least identified three roles of FDI to innovation, which will be analyzed further. First, FDI could role as a trigger variable of innovation activities. Second, FDI could also role as a moderation effect that strengthens innovation success. Third, FDI plays a role as an object affected by innovation itself.

It's very important to understand the relation between FDI and innovation (Kalande, 2002), cause a lot of research shows that FDI plays a vital role in the economic development process. One of the real proves is how FDI plays important role in opening China to the world, in providing new technology and providing finance needs (Li et al, 2018). That's why this study needs to do to analyze the FDI role to the success of Asia countries in commercializing high tech innovation, in which the success of commercialize innovation will be proxy with the value of high tech export. Meanwhile, innovation, as described previously, will be proxy with scientific journal publication data (number of the published journals), number of the patent applications, and R\&D expenditure, which is the input of innovation to achieve knowledge and experience in process of getting technological capabilities.

\section{Theoretical Background}

Although many theories and studies show that innovation is important in a country to compete, but not all countries can do it. One of the reasons is because innovation activities need huge resources, especially financial resource. This is a difficult thing for Asia countries to do innovation activities in their countries because of many of 
the countries in lack of sufficient funds. The solution for Asia countries to do is to attract overseas investment as much as possible in form of foreign direct investment (FDI) because FDI is capital package, technology, and managerial skill, is the important source of two capital input of direct capital and knowledge transfer (Huang et al, 2012). Previous researches have proved that FDI contributes positively to activity development ( $\& \& D$ activities and patent application).

Gervais (2009) found that FDI has a positive effect to enhance R\&D expenditures in a country. Other research showed that FDI has a positive effect on the number of patent applications (Chen \& Chen, 2019). Furthermore, Erdal \& Gocer (2015) found that improvement of one value of FDI in a country will improve $0.83 \%$ the value of R\&D expenditure in that country, and also improve the increase of patent application number as $0.42 \%$. Meanwhile, some of the studies also agreed that FDI is the main factor that has a positive effect on the explode of export value in China and other countries, and one of them is high tech export value (Gu et al, 2008; Zang, 2006). In this research also use scientific journals published data to measure innovation activities, but the effect of FDI on the number of scientific internationally published journal has not been found by researchers who examined them empirically. So that in developing hypotheses based on logical thinking, if FDI has a positive effect on $R \& D$ expenditure, then there will be more research that could be published in form of the research journal, both by private parties, university and government.

Hypotheses 1 : FDI has a positive effect on the number of published journal Hypotheses 2 : FDI has a positive effect on the number of patent application Hypotheses 3 : FDI has a positive effect on R\&D expenditure Hypotheses 4 : FDI has a positive significant effect on high-tech export

Related to the effect of FDI to export value, even though previous research identified that FDI has important effect in increasing the export value of a country (Okechukwu et al, 2018; Bouras \& Raggad, 2015; Kutan \& Vuksic, 2007; Liu \& Shu, 2003). But other studies also get different results, that conclude FDI has not effect to export value of West Balkan (Selimi et al, 2016), developing countries (Harding \& Javorcik, 2012), short term in Pakistan (Khalil et al, 2013), Turkey (Akguc et al, 2013), even has negative effect to export performance of pharmaceutical products in India (Kuntluru et al, 2012). Because of quite intense conflicting results of previous research relate to FDI effect to export value in a country, then to mediate, in this study would try to see the effect of FDI to high tech product export value in Asia countries with innovation activities as moderator variables.

Hypotheses 5 : FDI has a positive effect on high-tech export if moderate by the number of published journal 
Hypotheses 6 : FDI has a positive effect on high-tech export if moderate by the number of patent application

Hypotheses 7 : FDI has a positive effect on high-tech export if moderate by R\&D

Besides can play a role as triggers of innovation activities in a country, FDI also has other's role as moderation variable which can increase the chance of successful innovation activities in a country. But unfortunately, this role received less attention from previous studies. The only research that can be found until this research is made related to the moderation effect of FDI is research from Ismail (2013), which found that FDI has a positive moderation effect that can increase the success of innovation in increasing the value of high tech product export. With the aim to add literature regarding the moderation influence of FDI, thus the research will also be researched how the moderation effect of FDI to relation between innovation activities and the value of high tech product export.

Hypotheses 8 : The number of published journal has a positive effect on high-tech export when moderated by FDI

Hypotheses 9 : The number of patent application has a positive effect on high-tech export when moderated by FDI

Hypotheses $10:$ R\&D expenditure has a positive effect on high-tech export when moderated by FDI

While many researchers are more focused on discovering how FDI affects innovation activities, some researchers are examining how the effects of innovation on FDI. Among them were Adams (2010), who examined how the influence of Intellectual Property Rights (including one of them is patent) to FDI in 75 developing countries with a 19-year time period, and found result that Intellectual Property Rights (IPR) is part of the infrastructure that supports foreign investment in R\&D, so the IPR is influential and positively correlated with FDI. Likewise, the influence of R\&D expenditure on FDI, Lin \& Yeh (2005) found that R\&D Expenditure is an important determinant of FDI decisions, and has a positive influence on FDI. This can be understood because the purpose of the foreign party invest in a country is surely to get profit. And the benefits can be obtained from the premium of innovation (Helmers \& Rogers, 2010), which is in the form of a monopoly on the sale of new products (Fontana, 2007) so as to increase profitability. In other words, investors will be interested in investing their money in countries that have strong $\mathrm{R} \& \mathrm{D}$ infrastructure and activities, as well as a good IPR protection system, so that the expected benefits from innovation premiums are not disturbed by imitation risk.

Hypothesis 11 : The number of published journal has a positive effect on FDI. Hypothesis 12 : R\&D expenditure has a positive effect on FDI.

Hypothesis 13 : The number of patent application has a positive effect on FDI. 
8

\section{Methodology}

In this study, the countries that become populations are sovereign countries in Asia, namely a number of 49 Asian countries based on id.wikipedia.org. Meanwhile the research sample was selected using the purposive sampling method based on the criteria each country have $R \& D$ expenditure data, the number of scientific journals published internationally, the number of patent applications, foreign direct investment net inflows and the value of high-tech export during the period 2002 2017, so that 21 countries were selected as a research sample.

Table 1. Research Samples Countries

\begin{tabular}{clclll}
\hline No. & Countries & No. & \multicolumn{1}{c}{ Countries } & No. & \multicolumn{1}{c}{ Countries } \\
\hline 1. & Armenia & 8. & Israel & 15. & Pakistan \\
2. & Azerbaijan & 9. & Japan & 16. & Philippines \\
3. & China & 10. & Jordan & 17. & Sri Lanka \\
4. & Georgia & 11. & Kazakhstan & 18. & Singapore \\
5. & Hong Kong & 12. & Korea, Rep. & 19. & Thailand \\
6. & India & 13. & Kyrgyz & 20. & Turkey \\
7. & Indonesia & 14. & Malaysia & 21. & Vietnam \\
\hline
\end{tabular}

The definition of each variable in the study, indicators, scale of measurement, and the source of the data can be seen in the following table:

Table 2. Definition of Variable Operations

\begin{tabular}{llcl}
\hline \multicolumn{1}{c}{ Variable } & \multicolumn{1}{c}{ Definition } & Unit & \multicolumn{1}{c}{ Data Source } \\
\hline $\begin{array}{l}\text { Number of } \\
\begin{array}{l}\text { Published } \\
\text { Journal } \\
\text { (Log_Journal) }\end{array}\end{array}$ & $\begin{array}{l}\text { Number of published research } \\
\text { documents }\end{array}$ & $\begin{array}{c}\text { Document } \\
\text { Total }\end{array}$ & $\begin{array}{l}\text { Scimago Journal \& } \\
\text { Country Rank } \\
\text { (scimagojr.com) }\end{array}$ \\
\hline $\begin{array}{l}\text { Number of } \\
\text { patent } \\
\text { applications } \\
\text { (Log_Patent) }\end{array}$ & $\begin{array}{l}\text { Number of patent applications } \\
\text { by residents }\end{array}$ & $\begin{array}{c}\text { Document } \\
\text { Total }\end{array}$ & $\begin{array}{l}\text { World Bank Data } \\
\text { (data.worldbank.org) }\end{array}$ \\
\hline $\begin{array}{l}\text { R\&D } \\
\text { expenditure } \\
\text { (RDE) }\end{array}$ & $\begin{array}{l}\text { The percentage of total } \\
\text { expenditure / expenditure for } \\
\text { research and development on } \\
\text { GDP }\end{array}$ & $\begin{array}{c}\text { Percentage } \\
\text { (Ratio) }\end{array}$ & $\begin{array}{l}\text { World Bank Data } \\
\text { (data.worldbank.org) }\end{array}$ \\
\hline $\begin{array}{l}\text { FDI } \\
\text { direct investment included in } \\
\text { the reporting economy of GDP }\end{array}$ & $\begin{array}{c}\text { Percentage } \\
\text { (Ratio) }\end{array}$ & $\begin{array}{l}\text { World Bank Data } \\
\text { (data.worldbank.org) }\end{array}$ \\
\hline $\begin{array}{l}\text { high-tech } \\
\text { export } \\
\text { (Log_HTE) }\end{array}$ & $\begin{array}{l}\text { The export value of products } \\
\text { with high R\&D intensity }\end{array}$ & $\begin{array}{c}\text { Current Total } \\
\text { US \$ }\end{array}$ & $\begin{array}{l}\text { World Bank Data } \\
\text { (data.worldbank.org) }\end{array}$ \\
\hline
\end{tabular}




\section{Empirical Findings}

In this study the variables used are Log_Journal, Log_Patent, RDE, FDI, and Log_HTE with descriptive statistical results as follows:

Table 3. Descriptive Statistics of Research Variables

\begin{tabular}{lrrrrr}
\hline \multicolumn{1}{c}{ Variable } & N & Minimum & Maximum & \multicolumn{1}{c}{ Mean } & Std. Deviation \\
\hline RDE & 336 & 0,04756 & 4,42859 & 0,97372 & 1,20773 \\
FDI & 336 & $-1,41727$ & 58,51874 & 6,18320 & 8,96283 \\
Log_HTE & 336 & 6,37306 & 11,74823 & 9,28196 & 1,48671 \\
Log_Paten & 336 & 1,32221 & 6,09541 & 2,99237 & 1,10779 \\
Log_Journal & 336 & 1,55630 & 5,72825 & 3,73493 & 0,90140 \\
\hline
\end{tabular}

Source: Processed Data (2019)

From the table above it is known that the average value of FDI obtained or received by countries in Asia is $6.18320 \%$ of the value of the country's gross domestic product (GDP), with a standard deviation of 8.96283 , which is the biggest standard deviation value from other research data. This indicates any gap in foreign investment received by countries in Asia.

Data processing is done by structural equation modeling (SEM) through the help of the SmartPLS program version 3.2.8. Before testing the hypothesis, it is necessary to do a goodness of fit test of the single indicator research model.

Table 4. R Square and Collinearity Statistics

\begin{tabular}{|c|c|c|c|c|c|c|c|c|c|c|}
\hline & \multicolumn{2}{|c|}{ Log_HTE } & \multicolumn{2}{|c|}{ Log_Journal } & \multicolumn{2}{|c|}{ Log_Patent } & \multicolumn{2}{|c|}{ RDE } & \multicolumn{2}{|c|}{ FDI } \\
\hline & VIF & $\begin{array}{c}\mathbf{R}^{2} \\
\text { Adj. }\end{array}$ & VIF & $\begin{array}{c}\mathbf{R}^{2} \\
\text { Adj. }\end{array}$ & VIF & $\begin{array}{c}\mathbf{R}^{2} \\
\text { Adj. }\end{array}$ & VIF & $\begin{array}{c}\mathbf{R}^{2} \\
\text { Adj. }\end{array}$ & VIF & $\begin{array}{c}\mathbf{R}^{\mathbf{2}} \\
\text { Adj. }\end{array}$ \\
\hline Log_HTE & & 0,186 & & & & & & & & \\
\hline Log_Journal & 1,343 & & & 0,014 & & & & & 1,220 & \\
\hline $\begin{array}{l}\text { Log_Journal- } \\
\text { FDI }\end{array}$ & 1,646 & & & & & & & & & \\
\hline Log_Patent & 1,601 & & & & & 0,058 & & & 1,398 & \\
\hline $\begin{array}{l}\text { Log_Patent- } \\
\text { FDI }\end{array}$ & 1,793 & & & & & & & & & \\
\hline RDE & 1,460 & & & & & & & 0,014 & 1,40 & \\
\hline RDE-FDI & 1,591 & & & & & & & & & \\
\hline FDI & 1,279 & & 1,000 & & 1,000 & & 1,000 & & & 0,054 \\
\hline $\begin{array}{l}\text { FDI- } \\
\text { Log_Journal }\end{array}$ & 1,646 & & & & & & & & & \\
\hline $\begin{array}{l}\text { FDI- } \\
\text { Log_Patent }\end{array}$ & 1,793 & & & & & & & & & \\
\hline FDI-RDE & 1,591 & & & & & & & & & \\
\hline
\end{tabular}

Source: Processed Data (2019) 
From the analysis that has been done, that the suitability test criteria have been met with the value of collinearity statistics (VIF) $<5$ ((Garson, 2016), which means that the model is good and deserves further testing, although the research model used is still relatively weak because the $\mathrm{R}$ squared value is still below 0.25 (Hair et al., 2010). Meanwhile, the path coefficient is obtained as shown in Figure 1. However, given the complexity of this research model, However, given the complexity of this research model, and not allowing it to conduct reciprocal testing in SmartPLS (FDI to Log_Journal and vice versa, FDI to Log_Patent and vice versa and FDI to RDE and vice versa), so the research model is split into two, as shown in Figure 2 and 3.

When viewed from the path coefficient of the research model, it is known that FDI, in general, has a negative effect on the innovation activities of countries in Asia, whether it's the Log_Journal, Log_Patent or RDE variables. The only variable that is positively influenced by FDI is the Log_HTE variable which represents the export value of high-tech products in Asian countries.

The results of testing the research hypothesis can be seen in table 5 below:

\section{Tabel 5. Hypotheses Test Result}

\begin{tabular}{lrl}
\hline Variable Relationship & T Statistics & P Values \\
\hline FDI -> Log_Journal & 2,806 & $0,005^{* * *}$ \\
FDI -> Log_Patent & 5,785 & $0,000^{*}$ \\
FDI -> RDE & 2,592 & $0,010^{* *}$ \\
FDI -> Log_HTE & 2,616 & $0,009^{* *}$ \\
FDI-Log_Journal -> Log_HTE & 2,654 & $0,008^{* *}$ \\
FDI-Log_Patent -> Log_HTE & 0,466 &, 642 \\
FDI-RDE -> Log_HTE & 1,406 & 0,160 \\
Log_Journal-FDI -> Log_HTE & 2,654 & $0,008^{* *}$ \\
Log_Patent-FDI -> Log_HTE & 0,454 & 0,650 \\
RDE-FDI -> Log_HTE & 1,402 & 0,161 \\
Log_Journal -> FDI & 1,129 & 0,259 \\
Log_Patent -> FDI & 4,451 & $0,000^{*}$ \\
RDE -> FDI & 0,067 & 0,947 \\
* p < 0,01, ** p < 0,05, *** p < 0,1 & & \\
Source: Processed Data $(2019)$ & &
\end{tabular}

Based on the above results, a decision can be made regarding the hypothesis testing conducted, as summarized in the table 6 . 


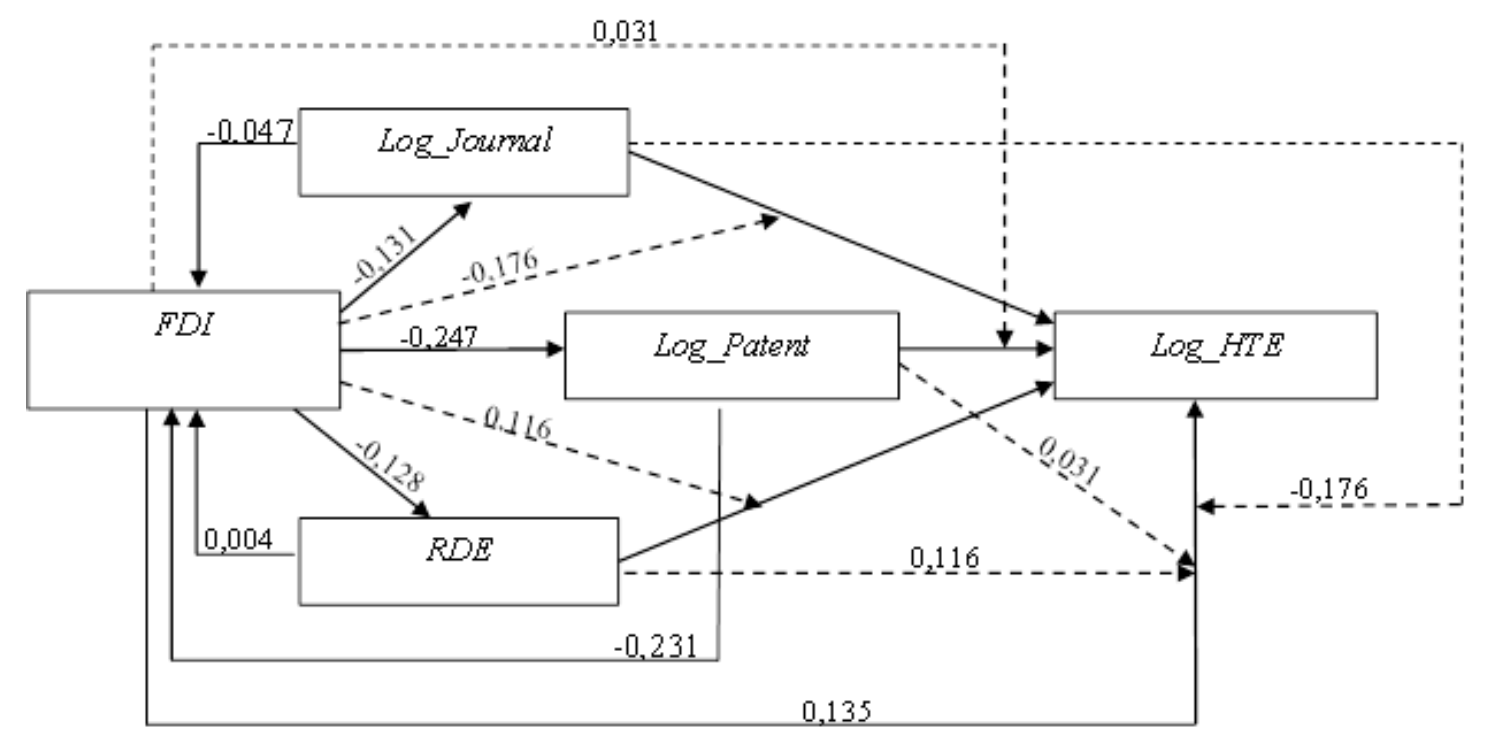

Figure 1. Path Coefficient of the Research Model

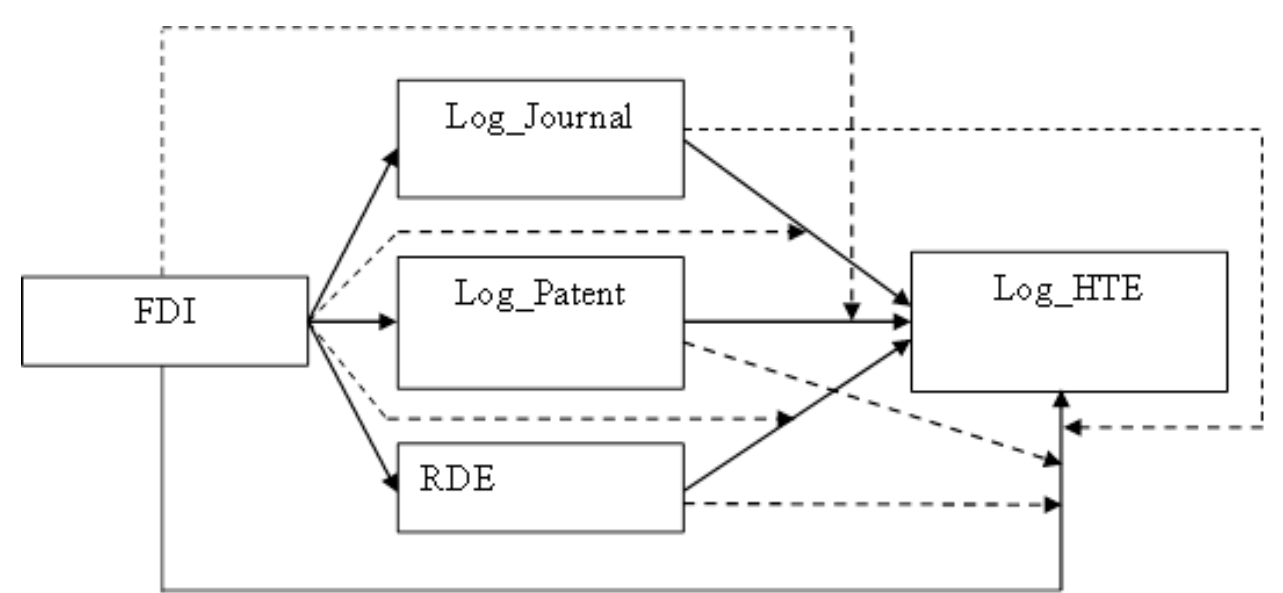

Figure 2. The Role of FDI as a Trigger and Variable of Moderation

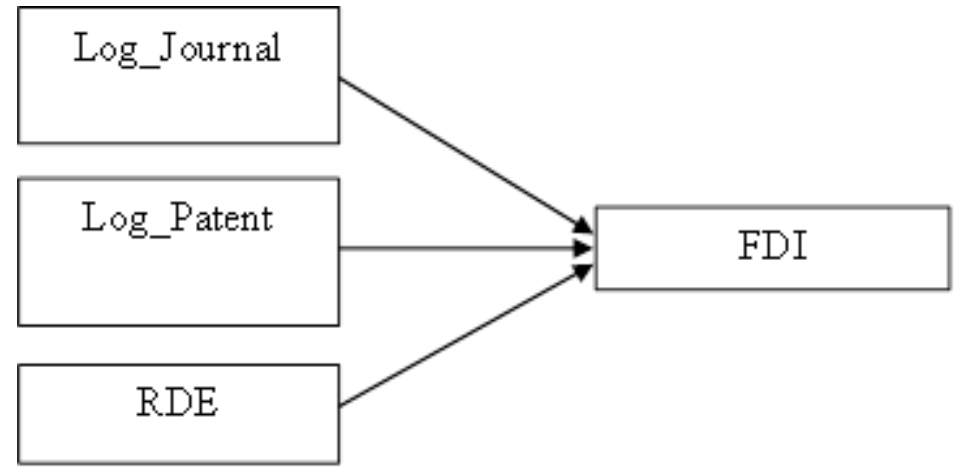

Figure 3. The Role of FDI as Influenced Factor 
Table 6. Hypotheses Test Decision

\begin{tabular}{cccccc}
\hline Hypothesis & $\begin{array}{c}\text { Exogenous } \\
\text { Variable }\end{array}$ & $\begin{array}{c}\text { Endogenous } \\
\text { Variable }\end{array}$ & $\begin{array}{c}\text { Moderation } \\
\text { Variable }\end{array}$ & $\begin{array}{c}\text { Direction of } \\
\text { Influence }\end{array}$ & Decision \\
\hline Hypothesis 1 & FDI & Log_Journal & - & Negative & Rejected \\
Hypothesis 2 & FDI & Log_Patent & - & Negative & Rejected \\
Hypothesis 3 & FDI & RDE & - & Negative & Rejected \\
Hypothesis 4 & FDI & Log_HTE & - & Positive & Accepted \\
Hypothesis 5 & FDI & Log_HTE & Log_Journal & Negative & Rejected \\
Hypothesis 6 & FDI & Log_HTE & Log_Patent & Positive & Rejected \\
Hypothesis 7 & FDI & Log_HTE & RDE & Positive & Rejected \\
Hypothesis 8 & Log_Journal & Log_HTE & FDI & Negative & Rejected \\
Hypothesis 9 & Log_Patent & Log_HTE & FDI & Positive & Rejected \\
Hypothesis 10 & RDE & Log_HTE & FDI & Positive & Rejected \\
Hypothesis 11 & Log_Journal & FDI & & Negative & Rejected \\
Hypothesis 12 & Log_Patent & FDI & & Negative & Rejected \\
Hypothesis 13 & RDE & FDI & & Positive & Rejected \\
\hline Sol
\end{tabular}

Source: Processed Data (2019)

The interesting point of this analysis is regarding the excess value of the firms being analysed in the sample. Excess value for Whited-Wu-index (Whited and $\mathrm{Wu}, 2006$ ) is the only descriptive statistic of the constraint terciles that does not exceed the excess value calculated by the Kaplan-Zingales-index (Kaplan and Zingales, 1997). This may be explained possibly because the Whited-Wu-index (Whited and $\mathrm{Wu}$, 2006) is more affected by the low value of sales growth and industry sales growth. However, excess value still displays significantly lower values for financially constrained firms of the sample.

\section{Discussion}

\subsection{The Influence of FDI on RDE, Log_Patent, Log_Journal \& Log_HTE}

Data processing results prove that FDI significantly influences the innovation activities represented by RDE, Log_Patent, and Log_Journal. But even so, from the direction of its influence, it is known that FDI affects RDE, Log_Patent, and Log_Journal in a negative direction. Thus $\mathrm{H} 1, \mathrm{H} 2$ and $\mathrm{H} 3$ are rejected, which means that the FDI variable has no positive effect on RDE, Log_Patent, and Log_Journal, which means that FDI cannot be a trigger in terms of increasing research \& development activities, increasing the latest patented products, and increasing research activities contained in international scientific journal publications, both by universities, government and private parties. The results of this study are in line 
with the research of Singh (2006) who found that foreign investment into developing countries through multinational companies did not contribute anything to increase the country's innovation capability. Of course, the results of this study and the results of Singh's research (2006) are mutually reinforcing, because most Asia countries are still classified as developing countries. From the same table, it is known that FDI has a significantly positive effect on the Log_HTE variable, which means that $\mathrm{H} 4$ is accepted. This indicates that FDI actually has a role in providing capital and investment packages included it such as technology, skills, modern management, new processes, and so on (Khachoo \& Sharna, 2017), in which the investment packages are useful only for producing of innovation activity results. The results of this study are in line with the results of Kabaklarli et al (2018) which also found that FDI has a significant positive effect on the increase in the value of high-tech exports in OECD countries, and in the United States (SelectUSA, 2017). Thus it can be said that FDI has an important role in increasing the amount of production of high-tech products in a country, both in developed countries and developing countries.

\subsection{The Moderation Effect of RDE, Log_Patent \& Log_Journal}

Related to the effect of FDI on the high-tech export, this study also examined whether this influence can be magnified with the help of $R D E$, Log_Patent, and Log_Journal. From the results of research conducted it is known that RDE, Log_Patent, and Log_Journal can not help at all to strengthen the effect of FDI on high-tech export in Asia countries. Even if explored further, precisely with the influence of moderation from these variables, the influence of $F D I$ which was initially significantly positive on high-tech export, to be no significant effect. It even becomes negative with the moderation of the Log_Journal variable. This indicates that foreign investment entering countries in Asia through FDI has nothing to do with the population's innovation activities in these countries. The results of this study reinforce the findings of Gokmen et al. (2012) which states that for developed countries, the impact on the entry of $F D I$ is greater in increasing the country's innovation capability compared to developing countries. This is due to differences between developed and developing countries in terms of technological infrastructure and the level of knowledge and skills of human resources. Where developed countries already have infrastructure and a better level of human resource capability, so that the transfer of technology \& knowledge that comes in conjunction with FDI can take place more quickly (Gokmen \& Turen, 2013). The results of this study also indicate that foreign investment in Asia countries is generally a form of investment from multinational companies that want to find the right location to produce their products. Their aim is nothing but to find a country with a much lower cost of production factors. 


\subsection{The Influence of RDE, Log_Patent \& Log_Journal on FDI}

Another question to be answered in this research is whether the innovation activities undertaken by countries in Asia can attract foreign investment $(F D I)$. The results of the study found that the innovation activities measured through RDE, Log_Patent, and Log_Journal do not have a significant positive effect on $F D I$, which means that innovation activities undertaken by countries in Asia cannot attract foreign investment. This result corroborates the previous statement that in general FDI has nothing to do at all with the activities of resident innovation in countries in Asia. Foreign investment coming into countries in Asia is an entire package brought from the origin country, including plans for products to be produced. Where high-tech products that they bring to be produced in Asia are the result of research and development from their home countries. These results reinforce the statement of Paul \& Singh (2017) which states that FDI is a form of investment in tangible assets foreign company's to produce or market products. The tangible asset is an investment in building factories in low-cost countries so that they can produce goods for export at a lower cost (Aulakh et al, 2000). That means the countries in Asia are only used as a place to produce and market their products, without being followed by any innovation activities carried out in these countries.

\subsection{The Effect of FDI Moderation}

The results of this study indicate that even with the help of $F D I$, published scientific journals cannot positively influence the export value of high-tech products. Meanwhile for the influence of Log_Patent and RDE, with the help of $F D I$ can increase the value of $L o g \_H T E$, which is marked by a positive direction of influence. Of course, this reinforces the previous statement which states that Asia countries have limited capital, technology and skills that make them unable to transform their $\mathrm{R} \& \mathrm{D}$ results and patents into the latest high-tech products and produce them. But with a foreign investment package in the form of $F D I$ at least they can help countries in Asia increase the export value of their high-tech products, even though it is not statistically significant. Thus statistically it can be stated that $\mathrm{H} 8, \mathrm{H} 9$, and $\mathrm{H} 10$ are rejected.

\section{Conclusions}

The only role of FDI that can be proven in this study is only as a provider of capital, technology, and modern management needs to produce high-tech 
products in Asia. In other words, FDI channeled to countries in Asia is a pure investment to get greater profits from multi-national companies, by increasing their profit margins by looking for countries in Asia that have the costs of production factors that are cheaper. Meanwhile, for R\&D activities, they do it in their home countries. The results of the $R \& D$ activity, if registered with a national patent agency in an approved country, will be selected as a non-resident patent application. If this scenario happens, then, of course, FDI can only boost the amount of production of high-tech products, without being able to boost innovation activities in countries in Asia in general. Although it is also possible if seen per individual country in Asia, there are several countries whose innovation activities are boosted due to FDI, as is the case in China. But for other countries in Asia, this statement needs to be proven by subsequent researchers.

\section{Acknowledgements}

This research supported by The Ministry of Research and Higher Education of the Republic of Indonesia, through the Beginner Lecturer Research Scheme for the fiscal year 2019 .

\section{References:}

Adams, Samuel. (2010). Intellectual Property Rights, Investment Climate and FDI in Developing Countries. International Business Research Vol. 3, No. 3; July 2010.

Akguc, Aslı., Meltem, Alıc1 \& Ucal, Sengün. (2013). FOREIGN DIRECT INVESTMENT, EXPORTS and OUTPUT GROWTH of TURKEY: CAUSALITY ANALYSIS Paper to be Presented at the European Trade Study Group (ETSG) Fifth Annual Conference.

Akoum, Ibrahim. (2016). Research, Development and Innovation In Malaysia: Elements of An Effective Growth Model. Asian Economic and Fiancial Review, 2016, 6(7): 390-403.

Anwar, Sajid \& Sun, Sizhong. (2014). Entry of foreign firms and R\&D behaviour: A panel data study of domestic and foreign firms in China. Economics of Innovation and New Technology. 23.

Aulakh, P. S., Kotabe, M., \& Teegen, H. (2000). Export Strategies and Performance of Firms from Emerging Economies: Evidence from Brazil, Chile, and Mexico. The Academy of Management Journal, 43(3), 342-361.

Bouras, H. \& Raggad, Bechir. (2015). Foreign direct investment and exports: Complementarity or substitutability an empirical investigation. International Journal of Economics and Financial Issues, 2015, 5(4), 933941.

Braunerhjelm, P. dan Thulin, P. (2008). Can countries create comparative advantages? R\&D expenditures, high-techexports and country size in 19 
OECD countries, 1981-1999. International Economic Journal, Vol. 22, No. 1, 95-111.

Chen, Yufen \& Chen, Jin. (2009). The impact of FDI on regional technological capabilities: evidence from China. Journal of Knowledge-based Innovation in China, Vol. 1Issue: 2, pp.143-158, https://doi.org/10.1108/17561410910949391

Erdal, L., \& Göçer, İ. (2015). The Effects of Foreign Direct Investment on R\&D and Innovations: Panel Data Analysis for Developing Asian Countries. Procedia - Social and Behavioral Sciences, 195, 749-758.

Fontana, Roberto \& Nesta, Lionel. (2008). Product Innovation and Survival in a High-Tech Industry. Review of Industrial Organization. 34. 10.1007/s11151-009-9210-7.

Garson, G. David. 2016. Partial Least Squares (PLS-SEM): 2016 Edition. Statistical Associates Publishing, Asheboro.

Gervais D. J.(2009). (Re)implementing the Agreement on Trade-Related Aspects of Intellectual Property Rights to Foster Innovation.The Journal of World Intellectual Property. 12 (5) 348-370.

Ghazal, R., \& Zulkhibri, M. (2015). Determinants of innovation outputs in developing countries. Journal of Economic Studies, 42(2), 237-260.

Gokmen, Y, Turen, U. \& Dilek, H. (2012). The Association between Foreign Direct Investors' Country Selection Decision and Economic Freedom Index. Finans Politik \& Ekonomik Yorumlar, 49(568): 5-20.

Gokmen, Yunus \& Turen, Ufuk. (2013). The Determinants of High Technology Exports Volume: A Panel Data Analysis of EU-15 Countries. International Journal of Management, Economics and Social Sciences 2304 - 1366. 2. $217-232$.

Gu, Weishi \& Awokuse, Titus \& Yuan, Yan. (2008). The Contribution of Foreign Direct Investment to China's Export Performance: Evidence from Disaggregated Sectors. American Agricultural Economics Association (New Name 2008: Agricultural and Applied Economics Association), 2008 Annual Meeting, July 27-29, 2008, Orlando, Florida.

Hair, Joseph F. JR, Rolph E Anderson, Ronald L. Tatham, \& William C. Black. 2010. Multivariate Data Analysis. Seventh edit. Prentice Hall Internatiional, inc.

Harding, Torfinn \& Javorcik, Beata. (2012). Foreign Direct Investment and Export Upgrading. Review of Economics and Statistics - REV ECON STATIST. 10.1162/REST_a_00226.

Helmers, Christian \& Rogers, Mark . (2010). Innovation and the Survival of New Firms in the UK. Rev Ind Organ (2010) 36:227-248.

Huang, Lingyun \& Liu, Xiaming \& Xu, Lei. (2012). Regional Innovation and Spillover Effects of Foreign Direct Investment in China: A Threshold Approach. Regional Studies. 46. 583-596.

Igor, Prodan. (2005). Influence of Research and Development Expenditures On Number Patent Applications: Selected Case Studies In OECD Countries 
and Central Europe, 1981-2001. Applied Econometrics and International Development, Vol. 5-4, 5-2

Ilmi, Nadia. (2017). The Impact Of Innovation And Foreign Direct Investment (FDI) And Its Interaction To Export Value Of High-Technology Products Of Asian-10. Journal of Developing Economies,. June 2017; 02(1): 50-59 ISSN : 2541-1012

Ismail, Normaz wana. (2013). Innovation and High-Tech Trade in Asian Countries. International Conference on Recent Developments in Asian Trade Policy and Integration, 20th and 21st February, 2013.

Ivus, Olena. (2010). Do Stronger Patent Rights Raise High-Tech Exports to the Developing World?. Journal of International Economics, Volume 81, Issue 1, May 2010, Pages 38-47.

Javorcik, B. Smarzynska, (2004). The composition of foreign direct investment and protection of intellectual property rights: Evidence from transition economies. European Economic Review 48 (2004) 39- 62.

Kabaklarli, E., Duran, M.S., \& Ucler, Y.T. (2018). The Determinants Of HighTechnology Exports : A Panel Data Approach For Selected Oecd Countries. Forum Scientiae Oeconomia, Volume 6 (2018), No. 2.

Kalande, Christopher M. (2002). "Intellectual property, foreign direct investment and the least -developed countries", Journal of World Intellectual Property, 5, 1, pp.11-128.

Khachoo, Qayoom \& Sharma, Ruchi. 2017. FDI and Incumbent R\&D Behavior: Evidence From Indian Manufacturing Sector. Journal of Economic Studies, Vol. 44 Issue: 3,pp.380-399, https://doi.org/10.1108/JES-10-20150188

Khalil, Samina \& Hussain, Iftikhar \& Memon, Manzoor. (2013). Foreign Direct Investment (FDI) and Exports: A Growth Nexus Revisited. International Journal of Asian Social Science. 3. 2170-2182.

Khan, Muhammad \& Samad, Ghulam. (2010). Intellectual property rights and foreign direct investment: Analysis of 14 South and South East Asian countries, 1970-2005. Applied Econometrics and International Development. 10.

Kuntluru, Sudershan., Muppani, Venkata Reddy., Akbar, Mohammad \& Khan, Ali. (2012). Foreign Direct Investment and Export Performance of Pharmaceutical Firms in India: An Empirical Approach. International Journal of Economics and Finance. 4. 10.5539/ijef.v4n5p216.

Kutan, Ali \& Vuksic, Goran. (2007). Foreign Direct Investment and Export Performance: Empirical Evidence. Comparative Economic Studies. 49. 430-445.

Lesser, W. (2002). The Effects of intellectual property rights on foreign direct investment and imports in developing countries. IP Strategy Today No. 4, pp. 1-16.

Li, Zheng \& Li, Jun \& He, Bin. (2018). Does foreign direct investment enhance or inhibit regional innovation efficiency?: Evidence from China. Chinese Management Studies, Vol. 12 Issue: 1, pp.35-55. 
Lin, H. \& Yeh, R.S.(2005).The interdependence between FDI and R\&D: an application of an endogenous switching model to Taiwan's electronics industry. Applied Economics, 37(15), 1789-1799.

Liu, X., \& Shu, C. (2003). Determinants of Export Performance: Evidence from Chinese Industries. Economics of Planningas of 2002, Incorporating 'MOCT-MOST: Economic Policy in Transitional Economies', 36(1), 4567.

Melkers, J., Bulger, D., \& Bozeman, L. (1993). Technology transfer and economic development. In: R. Bingham \& R. Mier (Eds.), Theories of local economic development: Perspectives from Across the Disciplines, pp. 232247.

Okechukwu, O., De Vita, G. and Luo, Y. (2018), "The impact of FDI on Nigeria's export performance: a sectoral analysis", Journal of Economic Studies, Vol. 45 No. 5, pp. 1088-1103.

Papadakis, M. (1993). Patents and the Evaluation of R\&D. In: Bozeman B., Melkers J. (eds) Evaluating R\&D Impacts: Methods and Practice. Springer, Boston, MA.

Paul, Justin \& Singh, Gurmeet. (2017). The 45 years of foreign direct investment research: Approaches, advances and analytical areas. The World Economy. 10.1111/twec. 12502 .

Prasanna, N. (2010). Impact of Foreign Direct Investment on Export Performance in India. J Soc Sci, 24(1): 65-71.

Sandu, Steliana \& Ciocanel, Bogdan. 2014. Impact of R\&D and Innovation on HighTech Export. Procedia Economics and Finance 15 (2014) 80-90.

SelectUSA. (2017). High-Tech Industries The Role of FDI in Driving Innovation and Growth 2017. U.S. Department of Commerce.

Selimi, Dr.Sc., Sadiku, Luljeta \& Reçi, MA. (2016). The Impact of Foreign Direct Investment on the Export Performance: Empirical Evidence for Western Balkan Countries:. ILIRIA International Review. 6. 57.

Singh, Lakhwinder. (2006). Innovations, High-Tech Trade and Industrial Development. UNU World Institute for Development Economics Research (UNU-WIDER), Research Paper No. 2006/27,

Yang, Chih-Hai \& Huang, Yi-Ju. (2009). Do Intellectual Property Rights Matter to Taiwan's Exports? A Dynamic Panel Approach. Pacific Economic Review, Vol. 14, Issue 4, pp. 555-578.

Zhang, Kevin Honglin. (2006). FDI and Host Countries' Exports: The Case of China. Economia Internazionale / International Economics, Camera di Commercio Industria Artigianato Agricoltura di Genova, vol. 59(1), pages 113-127. 